\title{
Progesterone modulation of gonadotropin secretion by dispersed rat pituitary cells in culture. IV. Follicle-stimulating hormone synthesis and release
}

\author{
Lewis C. Krey ${ }^{a}$, Vasantha Padmanabhan ${ }^{b}$ and Inese Z. Beitins ${ }^{b}$ \\ ${ }^{a}$ Laboratory of Neuroendocrinology, The Rockefeller University, New York, NY 10021, USA, and ${ }^{b}$ Division of Pediatric Endocrinology, \\ University of Michigan Medical School, Ann Arbor, MI 48109, USA
}

(Received 13 April 1992; accepted 29 September 1992)

Key words: Progesterone; Follicle-stimulating hormone; Gonadotroph, bioactivity, immunoactivity; (Rat pituitary)

\section{Summary}

Estradiol-treated, rat pituitary cells were studied to examine the effects of progesterone $(\mathrm{P})$ on follicle-stimulating hormone (FSH) synthesis and secretion. Progesterone was administered prior to or concurrent with $3 \mathrm{~h}$ secretory challenges with either gonadotropin-releasing hormone $(\mathrm{GnRH})$, the iontophore $\mathrm{A} 23187$, the protein kinase $\mathrm{C}$ activator phorbol 12,13-myristate (PMA), or no secretagogue. Medium FSH levels and cell FSH stores were quantified by radioimmunoassay and bioassay. Acute $(<6 \mathrm{~h})$ exposures to $\mathrm{P}$ increased medium levels of immunoreactive and bioactive FSH following GnRH challenge without influencing total (cell + medium) values whereas chronic (9-24 h) treatments increased both parameters. Chronic P elevated total FSH levels even when no secretagogue was present.

Studies with antiprogestins, $5 \alpha$-dihydroprogesterone and $5 \alpha$-reductase inhibitors revealed that this direct action of $\mathrm{P}$ depended on progestin receptor occupation but not on $5 \alpha$-reduction. These studies indicate that $\mathrm{P}$ selectively increases bioactive and immunoactive FSH levels, presumably by increasing FSH synthesis, and characterize the time course and cellular mechanisms of this response. To accommodate for P modulation of total FSH levels, FSH secretion was standardized as the percentage of cellular stores available for release. Progesterone modulation of GnRH-stimulated FSH secretion was multiphasic, i.e. increased at $0-6 \mathrm{~h}$, unchanged at $9 \mathrm{~h}$ and suppressed at $24 \mathrm{~h}$. Acute and chronic exposures to P similarly modulated A23187-stimulated FSH release, whereas both P treatments increased PMA-stimulated FSH secretion. In these experiments P modulated luteinizing hormone secretion in parallel fashion, suggesting that common cellular mechanisms underlie peptidergic and steroidal regulation of the secretion of both gonadotropins.

\section{Introduction}

Our understanding of the cellular mechanisms underlying progesterone (P) regulation of rat gonadotroph function in vitro has been derived primarily from studies on luteinizing hormone (LH) synthesis and secretion (Hsueh et al., 1979; Lagace et al., 1980; Tang, 1980; Drouin and Labrie, 1981; Turgeon and Waring, 1981, 1983, 1990; Kiesel et al., 1987; Ortmann et al., 1989; Krey and Kamel, 1990a,b; Krey et al., 1990). Only Labrie and his coworkers have examined

Correspondence to: Lewis C. Krey, Laboratory of Neuroendocrinology, The Rockefeller University, 1230 York Avenue, New York, NY 10021, USA. the temporal characteristics of $\mathrm{P}$ modulation of follicle-stimulating hormone (FSH) by estrogen-treated gonadotrophs, noting that acute $(<6 \mathrm{~h})$ and chronic ( $\geqq 24 \mathrm{~h}$ ) pretreatments increase the level of FSH secreted into the medium in response to gonadotropinreleasing hormone (GnRH; Drouin and Labrie, 1980; Lagace et al., 1980). This latter observation is unusual since chronic $\mathrm{P}$ dramatically suppresses LH secretion. However, Drouin and Labrie (1981) also reported that chronic exposures to $\mathrm{P}$ increased total (cell + medium) FSH levels without influencing total $\mathrm{LH}$ levels. Recently, we confirmed that a $24 \mathrm{~h}$ treatment with $\mathrm{P}$ prior to GnRH challenge increases FSH and suppresses LH levels in medium and selectively increases cell stores of FSH available for release (Krey and Kamel, 1990c). However, when we accounted for the changes in cell 
levels by calculating secretion as gonadotropin released in medium/total gonadotropin available for release, we observed declines in the secretion of both hormones, suggesting that chronic $P$ treatment suppresses all secretory responses to GnRH. We now extend this observation by characterizing several aspects of $\mathrm{P}$ control of FSH synthesis and secretion: describing the temporal parameters of $\mathrm{P}$ modulation of FSH secretion stimulated by $\mathrm{GnRH}$, the $\mathrm{Ca}^{2+}$ iontophore $\mathrm{A} 23187$ and a phorbol ester; examining the influences of $\mathrm{P}$ on FSH bioactivity; and analyzing the intracellular mechanisms involving $\mathrm{P}$ processing and the expression of its actions.

\section{Materials and methods}

Anterior pituitary glands were collected from female Sprague-Dawley rats (Charles River Labs, Kingston, NY, USA; Taconic Farms, Germantown, NY, USA), dispersed enzymatically to single cell preparations, and plated at $4.5-5 \times 10^{5}$ cells $/ 35 \mathrm{~mm}$ culture dish containing $1.5 \mathrm{ml}$ of Dulbecco's modified Eagle's medium containing $1 \%$ non-essential amino acids, $25 \mathrm{mM}$ Hepes, $100 \mu \mathrm{g} / \mathrm{ml}$ streptomycin sulfate, $100 \mathrm{U} / \mathrm{ml}$ penicillin $\mathrm{G}$ and $10 \%$ and $2.5 \%$ dextran + charcoalstripped horse and fetal calf serum (DMEMS). The procedures and reagents used to disperse and culture the cells have been described (Krey and Kamel, 1990a).

Estradiol $\left(\mathrm{E}_{2}\right), \mathrm{P}$ and $5 \alpha$-pregnan-3,20-dione $(5 \alpha$ DHP) were purchased from Steraloids (Wilton, NH, USA); the synthetic progestin RU5020 and antiprogestin RU486 were provided by Roussel (Romaineville, France). Flutamide was supplied by Schering (Bloomfield, NJ, USA); the $5 \alpha$-reductase inhibitor $17 \beta-N, N$ diethylcarbamoyl-4-methyl-4-aza- $5 \alpha$-androstan-3-one
(4MA) was the gift of Dr. G.H. Rasmussen (Merck, Sharp and Dohme, Rahway, NJ, USA). Steroids were diluted in ethanol and added to media at $1: 100$ $1: 10,000$. Synthetic GnRH was purchased from Beckman Instruments (Palo Alto, CA, USA) and Calbiochem (LaJolla, CA, USA), diluted in saline at $10^{-5}$ $\mathrm{M}$ and stored frozen at $-20^{\circ} \mathrm{C}$ until use. A23187 and phorbol 12-myristate 13-acetate (PMA) were purchased from Sigma (St. Louis, MO, USA), diluted in dimethyl sulfoxide to $10^{-2}-10^{-3} \mathrm{M}$ and stored at $-20^{\circ} \mathrm{C}$.

The experimental design has been described previously (Krey and Kamel, 1990a,b; Krey et al., 1990) and resembles that of Lagace and coworkers (1980). At 72 $\mathrm{h}$ after culture in $90 \%$ air: $10 \% \mathrm{CO}_{2}$, medium was collected and replaced with $1.5 \mathrm{ml}$ DMEMS containing $10^{-9} \mathrm{M} \mathrm{E}_{2}$. Secretory challenges were initiated $48 \mathrm{~h}$ later. Progestcronc $\left(10^{-7} \mathrm{M}\right)$, a concentration which closely approximates the periovulatory levels in the circulation of rats (Freeman et al., 1975), was added at varying time periods prior to and/or concurrently with the secretagogue. In some studies the P stimulus was 'interrupted' - medium was removed and the cells washed $4 \times$ with $1.5 \mathrm{ml}$ DMEM prior to replacement with DMEMS $+\mathrm{E}_{2} \pm \mathrm{P}$.

Secretory challenges consisted of two washes with $1.5 \mathrm{ml}$ DMEM and exposure to $1.5 \mathrm{ml}$ DMEM containing $\mathrm{E}_{2} \pm \mathrm{P}, 1 \mathrm{mM}$ bacitracin (Sigma, St. Louis, MO, USA) and the appropriate secretagogue. Medium was collected 1,2 or $3 \mathrm{~h}$ later and stored at $-20^{\circ} \mathrm{C}$. Cellular gonadotropin stores werc quantified post-challenge in cultures lysed by freezing-thawing twice in 1.5 $\mathrm{ml}$ buffer $(150 \mathrm{mM} \mathrm{NaCl}, 50 \mathrm{mM}$ Tris and $5 \mathrm{mM}$ EDTA, pH 7.4; Keel and Grotjan, 1985) containing 100

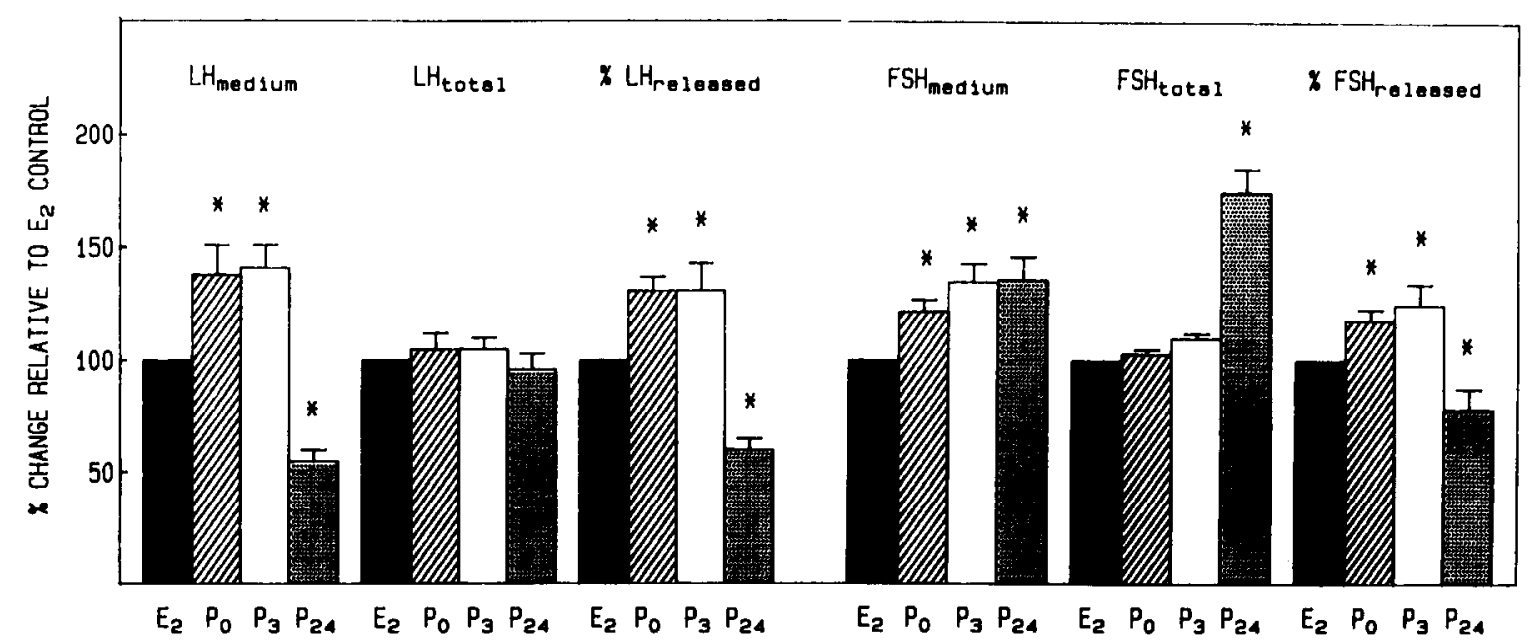

Fig. 1. Influences of different progesterone (P) treatments on GnRH-stimulated LH and FSH secretion hy pituitary cell cultures. The cells were exposed to $\mathrm{E}_{2}\left(10^{-9} \mathrm{M}\right)$ for $48 \mathrm{~h}$ prior to a $3 \mathrm{~h}$ challenge with $\mathrm{GnRH}\left(3 \times 10^{-10} \mathrm{M}\right)$. Progesterone (10 $\left.{ }^{-7} \mathrm{M}\right)$ was added either concurrently with $\left(\mathrm{P}_{0}\right)$ or 3 or $24 \mathrm{~h}$ prior to GnRH. Gonadotropin levels were quantified in medium and cell (total = medium + cell) and percent gonadotropin release calculated (medium/total). Data arc standardized as P-induced changes relative to $E_{2}$-treated control cells in three different cultures. $* p<0.005$ vs. $\mathrm{E}_{2}$ control (ANOVA and Bonferroni's $t$-test). 
TABLE

INFLUENCES OF ACUTE ( 2 h) AND CHRONIC ( 24 h) EXPOSURES TO P ON GnRH-STIMULATED LH AND FSH SECRETION AND THEIR TOTAL (MEDIUM + CELL) LEVELS

Cultures were harvested at 1,2 and $3 \mathrm{~h}$ after $\mathrm{GnRH}\left(3 \times 10^{-10} \mathrm{M}\right)$ treatment.

\begin{tabular}{|c|c|c|c|c|c|c|c|}
\hline & \multirow[t]{2}{*}{ Time } & \multicolumn{3}{|c|}{$\mathrm{LH}\left(\mu \mathrm{g} \mathrm{RP}_{1} /\right.$ culture $)$} & \multicolumn{3}{|c|}{ FSH (ng RP 2 /culture) } \\
\hline & & $\overline{\text { Medium }}$ & Total & $\%$ released & Medium & Total & \% released \\
\hline $\begin{array}{l}E_{2} \\
E_{2}+P_{2 h} \\
E_{2}+P_{24 h}\end{array}$ & $1 \mathrm{~h}$ & $\begin{array}{l}2.1 \pm 0.1 * \\
3.5 \pm 0.2 * * \\
1.3 \pm 0.1 * *\end{array}$ & $\begin{array}{l}11.2 \pm 0.1 \\
11.3 \pm 0.6 \\
10.6 \pm 0.5\end{array}$ & $\begin{array}{l}18.9 \pm 0.8 \\
31.2 \pm 3.1 * * \\
12.2 \pm 0.6 * *\end{array}$ & $\begin{array}{l}5.8 \pm 0.2 \\
8.2 \pm 0.5 * * \\
8.5 \pm 0.3 * *\end{array}$ & $\begin{array}{l}19.2 \pm 1.2 \\
24.1 \pm 1.3 \\
38.7 \pm 1.3 * *\end{array}$ & $\begin{array}{l}30.5 \pm 0.9 \\
33.9 \pm 1.4 \\
22.0 \pm 0.3 * *\end{array}$ \\
\hline $\begin{array}{l}E_{2} \\
E_{2}+P_{2 h} \\
E_{2}+P_{24 h}\end{array}$ & $2 \mathrm{~h}$ & $\begin{array}{l}5.5 \pm 0.4 \\
7.4 \pm 0.9 * * \\
2.3 \pm 0.2 * *\end{array}$ & $\begin{array}{r}11.3 \pm 1.2 \\
11.6 \pm 1.0 \\
8.7 \pm 0.4\end{array}$ & $\begin{array}{l}48.6 \pm 2.1 \\
64.0 \pm 2.5 * * \\
27.0 \pm 2.1 * *\end{array}$ & $\begin{array}{l}10.9 \pm 0.1 \\
13.7 \pm 0.2 * * \\
13.7 \pm 0.1 * *\end{array}$ & $\begin{array}{l}22.0 \pm 1.4 \\
25.8 \pm 1.6 \\
42.5 \pm 0.8 * *\end{array}$ & $\begin{array}{l}50.0 \pm 3.3 \\
53.4 \pm 3.0 \\
32.3 \pm 0.3 * *\end{array}$ \\
\hline $\begin{array}{l}E_{2} \\
E_{2}+P_{2 h} \\
E_{2}+P_{24 h}\end{array}$ & $3 \mathrm{~h}$ & $\begin{array}{l}5.5 \pm 0.2 \\
7.6 \pm 0.6 * * \\
3.0 \pm 0.4 * *\end{array}$ & $\begin{array}{r}9.5 \pm 0.6 \\
10.5 \pm 0.4 \\
8.8 \pm 0.6\end{array}$ & $\begin{array}{l}57.9 \pm 1.8 \\
71.6 \pm 2.3 * * \\
33.7 \pm 2.4 * *\end{array}$ & $\begin{array}{l}10.8 \pm 0.7 \\
16.9 \pm 0.5 * * \\
18.7 \pm 1.4 * *\end{array}$ & $\begin{array}{l}21.0 \pm 1.7 \\
26.7 \pm 0.4 \\
13.1 \pm 2.1 * *\end{array}$ & $\begin{array}{l}51.7 \pm 1.1 \\
63.2 \pm 2.3 * * \\
43.2 \pm 1.3 * *\end{array}$ \\
\hline
\end{tabular}

* Mean $\pm \operatorname{SEM}(n=4)$.

** $p<0.05$ vs. $\mathrm{E}_{2}$ control (ANOVA and Dunnett's test). This experiment has been replicated in three other cell preparations will similar results.

IU/ml Trasylol (FBA Pharmaceuticals, New York, NY, USA).

LH and FSH levels in medium and cell lysate samples were quantified by radioimmunoassay. The LH system utilized antiserum to oLH (GDN No. 15) and has been described (Krey and Kamel, 1990a). The FSH assay utilized reagents from the NIDDK kit: antirFSHS $_{11}$ as antibody, $\left[{ }^{125} \mathrm{I}\right] \mathrm{rFSHI}_{6}$ as tracer and $\mathrm{rFSHRP}_{2}$ or $\mathrm{rFSHI}_{7}$ as standard. Intraassay coefficient of variation averaged $10 \%$. FSH bioactivity was assessed by a rat Sertoli cell bioassay using $\mathrm{rFSHI}_{7}$ as standard (Padmanabhan et al., 1988). Assay sensitivity was $0.1 \mathrm{ng} \mathrm{rFSHI} /$ tube; intraassay coefficient of variation was $<12.5 \%$. Every sample from each experiment was run simultaneously in both assays.

Studies were routinely repeated in three or more different cell preparations; individual experiments were performed in triplicate or quadruplicate. Dose-response curves were run for GnRH $\left(10^{-11}-10^{-7} \mathrm{M}\right)$, and curve parameters werc calculated according to Rodbard et al. (1977) and tested for statistical differences between steroid treatments by analysis of variance for repeated measures and then dependent $t$-tests. In the other experiments, data were subjected to twoway analyses of variance using cell culture replication as a variable. Within- and among-group comparisons were made by analyzing the simple main effects; posthoc comparisons were made with Dunnett's test or Bonferroni's $t$-test. To minimize the impact of cultureto-culture variation in secretion and cell levels, some data has been standardized as percentage change relative to $E_{2}$ controls prior to presentation.

\section{Results}

Medium FSH levels secreted by cells exposed to $\mathrm{P}$ acutely $(<6 \mathrm{~h})$ and chronically $(24 \mathrm{~h})$ were consistently elevated above those of $\mathrm{E}_{2}$-treated controls regardless of the size or duration of the GnRH challenge (Fig. 1; Tables 1 and 2). However, whereas acute exposure to $P$ also elevated medium $\mathrm{LH}$ levels, chronic $\mathrm{P}$ exposure suppressed them. The influences of $\mathrm{P}$ on medium FSH levels were consistently characterized by increases in basal or maximal values but could not be attributed to any significant change in $\mathrm{ED}_{50}$ for $\mathrm{GnRH}$ (Table 2).

When cellular gonadotropins were quantified, total (cell + medium) FSH levels did not change following acute $\mathrm{P}$ but increased significantly within $24 \mathrm{~h}$; there were no comparable changes in total LH (Fig. 1; Table

\section{TABLE 2}

INFLUENCES OF ACUTE ( 3 h) AND CHRONIC ( 24 h) EXPOSURE TO $P\left(10^{-7} \mathrm{M}\right)$ ON PARAMETERS OF THE GnRH DOSE-RESPONSE CURVE FOR FSH SECRETION AS DEIERMINED BY ANALYSES OF MEDIUM FSH VALUES

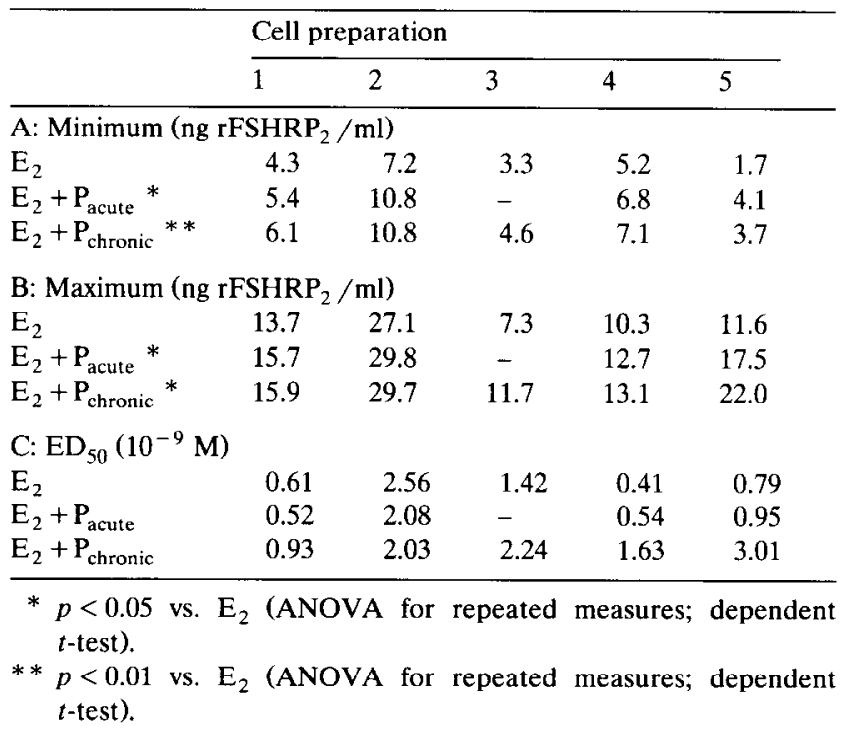




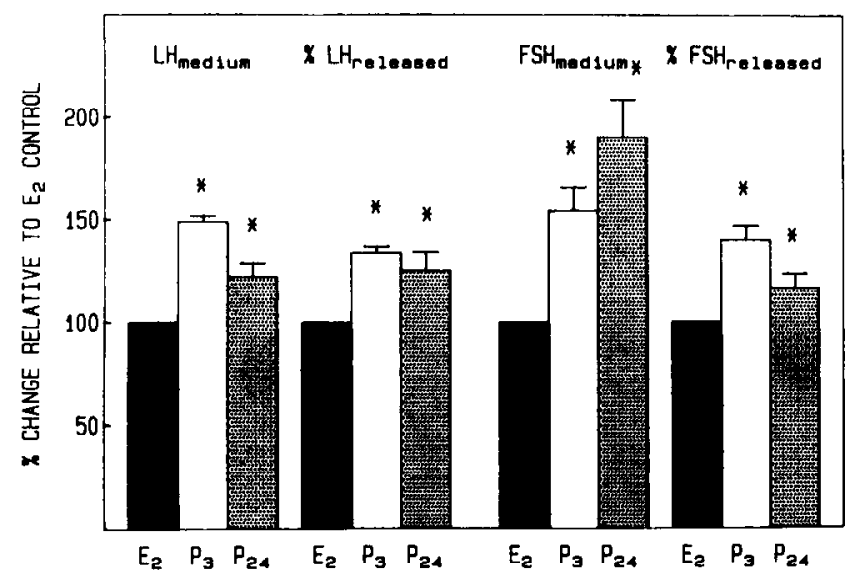

Fig. 2. Influences of different progesterone (P) treatments on PMAstimulated $\mathrm{LH}$ and FSH secretion by pituitary cell cultures. Data are standardized as $\mathrm{P}$-induced changes relative to $\mathrm{E}_{2}$-treated control cells in seven different cultures. ${ }^{*} p<0.005$ vs. $\mathrm{E}_{2}$ control (ANOVA and Bonferroni's $t$-test).

1). To accommodate for this variability in releasable gonadotropin stores, FSH (and LH) secretion was calculated as a percentage of the FSH (LH) stores available for release. These parameters displayed parallel biphasic patterns, being elevated with $\mathrm{P}_{\text {acute }}$ and suppressed with $\mathrm{P}_{\text {chronic }}$ treatment. FSH and I.H secretion progressively increased throughout the $3 \mathrm{~h} \mathrm{GnRH}$ challenge but consistently reflected the modulatory actions of $P_{\text {acute }}$ and $P_{\text {chronic }}$ treatments (Table 1).

The selective action of $P_{\text {chronic }}$ to increase total FSH was consistently observed with no secretagogue or when A23187 $\left(10^{-5} \mathrm{M}\right)$ and PMA $\left(10^{-7} \mathrm{M}\right)$ were used. In the absence of secretagogue, $P_{\text {chronic }}$ significantly increased total FSH over estrogen-treated controls by $142 \pm 7 \%$ (mean \pm SEM, $n=6, p<0.005$ ) as compared to $149 \pm 6 \%$ if the same cell preparations were challenged with $3 \times 10^{-10} \mathrm{M}$ GnRH. In three other cell preparations cotreated with GnRH, A23187 and PMA, $\mathrm{P}_{\text {chronic }}$ increased total FSH by $124 \pm 4 \%, 140+$ $4 \%$ and $130 \pm 8 \%$, respectively, over $\mathrm{E}_{2}$-treated controls; each increase was significant $(p<0.05)$.

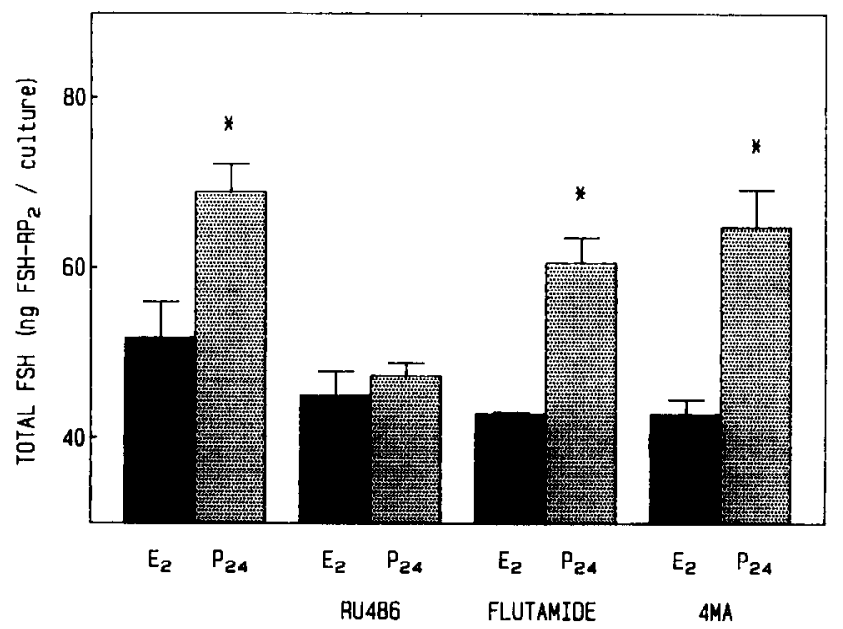

Fig. 3. Influences of the antiprogestin RU486, the antiandrogen flutamide and the $5 \alpha$-reductase inhibitor $4 \mathrm{MA}$ on P-induced increases in total (medium + cell) FSH levels. $\mathrm{P}\left(10^{-8} \mathrm{M}\right)$ was added 24 $\mathrm{h}$ prior to a $3 \mathrm{~h}$ challenge with GnRH; 100-fold molar excesses of the other compounds were added $1 \mathrm{~h}$ prior to $\mathrm{P}$. ${ }^{*} p<0.05$ vs. appropriate no-P control ( $t$-test); similar results were noted in three other cell preparations.

Progesterone modulation of A23187-stimulated FSH secretion depended on the percentage of cellular hormone released. When the iontophore released less than $50 \%$ of cell stores in $E_{2}$-treated controls, a secretion level routinely observed with the GnRH challenges, $\mathrm{P}_{\text {acute }}$ and $\mathrm{P}_{\text {chronic }}$ significantly $(p<0.05)$ enhanced $(129 \pm 7 \%, n=4)$ and suppressed $(86 \pm 9 \%)$ $\mathrm{FSH}$ release relative to $\mathrm{E}_{2}$-treated controls. However, in those cultures in which A23187 stimulated the release of $\geqq 65 \%$ of cell stores, FSH secretion was not increased by $\mathrm{P}_{\text {acute }}$ treatment $(97 \pm 3 \%, n=4)$, but was suppressed significantly $(80 \pm 5 \%, p<0.05)$ by $\mathrm{P}_{\text {chronic }}$. Significantly, the LH secretion pattern paralleled that for FSH in each A23187-treated culture. In marked contrast to the patterns obtained for $\mathrm{GnRH}$ and A23187, both $\mathrm{P}_{\text {acute }}$ and $\mathrm{P}_{\text {chronic }}$ treatments increased PMA-stimulated FSH and LH secretion (Fig. 2).

A second series of experiments examined the intracellular processing of $\mathbf{P}$ underlying the increase in total

TABLE 3

INFLUENCES OF CHRONIC EXPOSURES TO $5 \alpha$-DIHYDROPROGESTERONE ( $5 \alpha$-DHP) AND PROGESTERONE (P) ON TOTAL (MEDIUM + CELL) FSH LEVELS IN $E_{2}$-TREATED PITUITARY CELL CULTURES

\begin{tabular}{|c|c|c|c|c|c|}
\hline \multirow[t]{3}{*}{ Treatment } & \multicolumn{5}{|c|}{ Total FSH (ng rFSHRP ${ }_{2} /$ culture) } \\
\hline & \multicolumn{5}{|c|}{ Cell preparation } \\
\hline & $\overline{1}$ & 2 & 3 & 4 & 5 \\
\hline $\begin{array}{l}E_{2} \\
E_{2}+P\left(10^{-7} M\right) \\
E_{2}+5 \alpha-D H P\left(10^{-7} M\right)\end{array}$ & $\begin{array}{l}25.4 \pm 1.7 * \\
33.0 \pm 0.5 \\
29.3 \pm 1.0\end{array}$ & $\begin{array}{l}21.7 \pm 0.8 \\
41.0 \pm 5.0 \\
34.0 \pm 4.0\end{array}$ & $\begin{array}{l}34.1 \pm 2.9 \\
45.9 \pm 2.1 \\
31.8 \pm 2.2\end{array}$ & $\begin{array}{l}22.2 \pm 0.5 \\
25.5 \pm 0.8 \\
21.3 \pm 1.0\end{array}$ & $\begin{array}{l}14.8 \pm 0.8 \\
20.1 \pm 1.3 \\
21.2 \pm 1.0\end{array}$ \\
\hline
\end{tabular}

* Mean $\pm \operatorname{SEM}(n-3)$.

$p<0.005, \mathrm{E}_{2}$ vs. $\mathrm{E}_{2}+\mathrm{P} ; p<0.01, \mathrm{E}_{2}$ vs. $\mathrm{E}_{2}+5 \alpha$-DHP (ANOVA and Bonferroni's $t$-test). 
TABLE 4

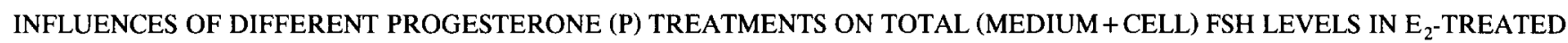
PITUITARY CELL CULTURES

\begin{tabular}{|c|c|c|c|c|c|c|}
\hline \multirow[t]{3}{*}{ Treatment } & \multicolumn{6}{|c|}{ Total FSH (ng rFSHRP $2 /$ culture) } \\
\hline & \multicolumn{6}{|c|}{ Cell preparation } \\
\hline & 1 & 2 & 3 & 4 & 5 & 6 \\
\hline \multicolumn{7}{|c|}{ A: $\mathrm{P}\left(10^{-7} \mathrm{M}\right)$ for $6 \mathrm{~h}$ immediately prior to $\mathrm{GnRH}$ challenge } \\
\hline $\mathrm{E}_{2}$ & $17.6 \pm 1.0^{*}$ & $25.8 \pm 1.5$ & $9.6 \pm 1.6$ & $20.2 \pm 1.3$ & $23.5 \pm 2.9$ & $24.2 \pm 7.0$ \\
\hline $\mathrm{E}_{2}+\mathrm{P}$ & $21.7 \pm 1.0$ & $31.1 \pm 1.9$ & $18.4 \pm 3.0$ & $27.9 \pm 3.9$ & $31.6 \pm 3.5$ & $23.9 \pm 1.2$ \\
\hline \multicolumn{7}{|c|}{ B: $P\left(10^{-7} \mathrm{M}\right)$ for $6 \mathrm{~h}$ beginning at $24 \mathrm{~h}$ prior to $\mathrm{GnRH}$ challenge } \\
\hline $\mathrm{E}_{2}$ & $9.0 \pm 1.0$ & $19.1 \pm 1.3$ & $24.9 \pm 0.8$ & $20.2 \pm 1.3$ & $23.5 \pm 2.9$ & $24.2 \pm 2.0$ \\
\hline$E_{2}+P$ & $14.6 \pm 0.5$ & $20.4 \pm 0.4$ & $30.4 \pm 1.8$ & $28.4 \pm 1.8$ & $27.1 \pm 2.4$ & $28.0 \pm 2.9$ \\
\hline
\end{tabular}

* Mean $\pm \operatorname{SEM}(n=3)$.

$p<0.005, \mathrm{E}_{2}$ vs. $\mathrm{E}_{2}+\mathrm{P}$ for both $6 \mathrm{~h} \mathrm{P}$ treatments (ANOVA).

FSH in $\mathrm{E}_{2}$-treated cells. Significantly, cotreatment with RU486 blocked the FSH response whereas the antiandrogen flutamide had no effect (Fig. 3). Cotreatment with a 100 -fold molar excess of 4MA also failed to block P's action on total FSH levels (Fig. 3), suggesting that $5 \alpha$-reduction of $P$ was not necessary. This hypothesis was supported further by observations that $5 \alpha$-DHP did not elevate total FSH levels more effectively than did $\mathrm{P}(121 \pm 13 \%$ vs. $141 \pm 13 \%$, respectively; Table 3$)$ and that RU5020, a synthetic progestin not subjected to $5 \alpha$-reduction, was as effective as P (data not shown).

In time-course studies, a $9 \mathrm{~h}$ exposure to $\mathrm{P}(6 \mathrm{~h}$ pretreatment $+3 \mathrm{~h}$ cotreatment with $\mathrm{GnRH}$ ) was suffi- cient to increase total FSH levels (Table 4). In contrast, $6 \mathrm{~h}$ of exposure $(3 \mathrm{~h}$ pretreatment $+3 \mathrm{~h}$ cotreatment with GnRH) did not elevate total FSH levels (Fig. 1). However, $6 \mathrm{~h}$ P treatments did elevate total FSH when the levels were monitored $18 \mathrm{~h}$ after terminating the exposure to $P$ (Table 4). Such 'interrupted' $P$ treatments produced greater elevations in total FSH when longer exposures to $\mathrm{P}$ or shorter termination intervals were studied (data not shown).

In a final series of experiments medium and cell FSH levels were quantified by radioimmunoassay and bioassay. $P_{\text {acute }}$ and $\mathrm{P}_{\text {chronic }}$ treatments produced significant changes in FSH bioactivity that were similar to

\section{TABLE 5}

INFLUENCES OF ACUTE ( 2 h) AND CHRONIC $(24 h)$ EXPOSURE TO P ON GnRH-STIMULATED IMMUNOREACTIVE AND BIOACTIVE FSH (FSH imm $_{\text {AND FSH }}$,io, RESPECTIVELY) SECRETION INTO MEDIUM AND THEIR TOTAL (CELL + MEDIUM) LEVELS. THE $B: I$ RATIOS FOR SECRETED FSH ARE ALSO PRESENTED

The four different culture preparations were exposed to GnRH $\left(3 \times 10^{-10} \mathrm{M}\right)$ for $3 \mathrm{~h}$.

\begin{tabular}{|c|c|c|c|c|c|c|}
\hline \multirow[t]{2}{*}{ Treatment } & \multirow[t]{2}{*}{ Preparation } & \multicolumn{2}{|c|}{$\begin{array}{l}\text { Medium FSH } \\
\left(\mathrm{ng} \mathrm{rFSHI}_{7} / \mathrm{ml}\right)\end{array}$} & \multirow[t]{2}{*}{$B: I$} & \multicolumn{2}{|c|}{ 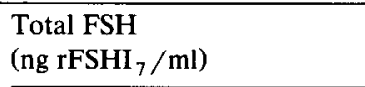 } \\
\hline & & $\overline{\mathrm{FSH}_{\mathrm{imm}}}$ & $\mathrm{FSH}_{\text {bio }}$ & & $\overline{\mathrm{FSH}_{\mathrm{imm}}}$ & $\mathrm{FSH}_{\text {bio }}$ \\
\hline $\begin{array}{l}E_{2} \\
E_{2}+P_{\text {acute }} \\
E_{2}+P_{\text {chronic }}\end{array}$ & 1 & $\begin{array}{l}2.9 \pm 0.1 \\
4.1 \pm 0.2 \\
4.6 \pm 0.7\end{array}$ & $\begin{array}{l}1.4 \pm 0.1 \\
1.5 \pm 0.4 \\
1.5 \pm 0.2\end{array}$ & $\begin{array}{l}0.48 \pm 0.03 \\
0.36 \pm 0.08 \\
0.31 \pm 0.08\end{array}$ & $\begin{array}{l}14.5 \pm 0.9 \\
14.2 \pm 0.9 \\
24.8 \pm 2.3\end{array}$ & $\begin{array}{l}11.5 \pm 0.1 \\
13.4 \pm 0.3 \\
18.5 \pm 6.3\end{array}$ \\
\hline $\begin{array}{l}E_{2} \\
E_{2}+P_{\text {acule }} \\
E_{2}+P_{\text {chronic }}\end{array}$ & 2 & $\begin{array}{r}8.4 \pm 1.4 \\
11.4 \pm 1.2 \\
10.9 \pm 1.1\end{array}$ & $\begin{array}{l}2.1 \pm 0.3 \\
3.1 \pm 0.4 \\
3.0 \pm 0.8\end{array}$ & $\begin{array}{l}0.27 \pm 0.06 \\
0.27 \pm 0.01 \\
0.27 \pm 0.04\end{array}$ & $\begin{array}{l}17.1 \pm 2.5 \\
29.0 \pm 2.8 \\
41.0 \pm 3.6\end{array}$ & $\begin{array}{r}5.3 \pm 1.0 \\
5.4 \pm 0.5 \\
12.1 \pm 3.1\end{array}$ \\
\hline $\begin{array}{l}\mathrm{F}_{2} \\
\mathrm{E}_{2}+\mathrm{P}_{\text {acute }} \\
\mathrm{E}_{2}+\mathrm{P}_{\text {chronic }}\end{array}$ & 3 & $\begin{array}{l}4.4 \pm 0.2 \\
5.4 \\
5.8 \pm 0.3\end{array}$ & $\begin{array}{l}1.8 \pm 0.1 \\
3.1 \pm 0.6 \\
2.9 \pm 0.2\end{array}$ & $\begin{array}{l}0.41 \pm 0.03 \\
0.40 \\
0.50 \pm 0.05\end{array}$ & $\begin{array}{l}10.1 \pm 0.4 \\
11.0 \\
16.0 \pm 1.0\end{array}$ & $\begin{array}{l}6.0 \pm 0.4 \\
6.8 \pm 0.8 \\
9.2 \pm 1.4\end{array}$ \\
\hline $\begin{array}{l}E_{2} \\
E_{2}+P_{\text {acute }} \\
E_{2}+P_{\text {chronic }}\end{array}$ & 4 & $\begin{array}{l}4.5 \pm 0.5 \\
7.5 \pm 0.3 \\
4.9 \pm 0.3\end{array}$ & $\begin{array}{l}2.2 \pm 0.1 \\
4.0 \pm 0.8 \\
2.5 \pm 0.3\end{array}$ & $\begin{array}{l}0.51 \pm 0.08 \\
0.54 \pm 0.10 \\
0.50 \pm 0.08\end{array}$ & $\begin{array}{l}18.2 \pm 1.1 \\
28.5 \pm 0.8 \\
25.2 \pm 0.8\end{array}$ & $\begin{array}{l}21.6 \pm 1.5 \\
16.0 \pm 1.2 \\
41.0 \pm 10.9\end{array}$ \\
\hline
\end{tabular}

\footnotetext{
* Mean $\pm \operatorname{SEM}(n=3)$.
}

$p<0.01, \mathrm{E}_{2}$ vs. $\mathrm{E}_{2}+\mathrm{P}_{\text {acute }}$ and $\mathrm{E}_{2}+\mathrm{P}_{\text {chronic }}$ for medium $\mathrm{FSH}_{\text {imm }}$ and $\mathrm{FSH}_{\text {bio }}$ (ANOVA and Bonferroni's $t$-test).

$p<0.01, \mathrm{E}_{2}$ vs. $\mathrm{E}_{2}+\mathrm{P}_{\text {chronic }}$ for total $\mathrm{FSH}_{\text {imm }}$ and $\mathrm{FSH}_{\text {bio }}$ (ANOVA and Bonferroni's $t$-test). 
those noted for FSH immunoactivity (Table 5). However, there was no significant change in $B: I$ for either the FSH secreted into the medium (Table 5) or retained in the cells (data not shown).

\section{Discussion}

The present studies on FSH secretion further illustrate that periovulatory concentrations of $P$ influence gonadotropin synthesis, storage and secretion by a direct action on gonadotrophs. The dramatic effect of $P_{\text {chronic }}$ treatments on cell FSH stores diverges markedly from previous observations for $\mathrm{LH}$ and suggests a direct and selective activation of FSH synthesis. In contrast, $\mathrm{P}_{\text {acute }}$ and $\mathrm{P}_{\text {chronic }}$ treatments modulate secretagogue-induced LH and FSH secretion in similar fashion, most likely via a common cellular mechanism(s). These progestational influences on FSH synthesis and secretion may play an important role in determining the temporal and quantitative aspects of periovulatory FSH secretion during the rat estrous cycle.

Our findings, like those of Drouin and Labrie (1981), indicate that $\mathrm{P}_{\text {chronic }}$ selectively increases cellular FSH stores in $\mathrm{E}_{2^{-}}$and $\mathrm{GnRH}$-treated rat pituitary cell cultures. Moreover, we report similarly sized increases with $\mathrm{A} 23187$ or PMA, or even in the absence of a secretagogue. This last observation conclusively demonstrates that this response is to a direct action of $\mathrm{P}$ on the gonadotroph. Significantly, chronic testosterone ( $\mathrm{T}$ ) also selectively increases total FSH levels in non- $E_{2}$-treated cells (Drouin and Labrie, 1976; Kennedy and Chappel, 1985; Krey and Kamel, 1991). In this regard, it is relevant that progestin and androgen receptors are primarily localized in gonadotrophs (DuBois et al., 1978; Sar and Stumpf, 1978, 1979; Thieulant and Duvall, 1985; Fox et al., 1990). Moreover, the present results with P and RU486 (Fig. 3) and the results of similarly designed studies with $\mathrm{T}$ and flutamide (Krey, unpublished observations) indicate that occupation of these receptors is necessary for the appropriate increases in FSH stores. In 1981 Drouin and Labric reportcd that $P$ increases cell FSH stores in non- $\mathrm{E}_{2}$-treated cell cultures, cultures presumably devoid of progestin receptors (Krey et al., 1990). Perhaps, under these experimental circumstances, $\mathrm{P}\left(10^{-7} \mathrm{M}\right)$ elevates cell FSH levels by interacting with resident androgen receptors (Handa et al., 1987).

In contrast to the importance of progestin receptors, $5 \alpha$-reductase activity does not appear to play an essential role in $\mathrm{P}$ actions on $\mathrm{FSH}$, even though this enzyme has been proposed to be important in androgen and progestin regulation of gonadotroph function (Denef et al., 1980; Martini, 1982). Such a conclusion is bascd on the observations that non-reducible progestins effectively increase cell FSH levels whereas $5 \alpha$-DHP is, if anything, slightly less effective than $\mathrm{P}$ and that $4 \mathrm{MA}$, at molar excesses sufficient to block $5 \alpha$-reduction in these cell cultures (Liang et al., 1983, 1984; Kamel and Krey, 1991), fails to influence $P$ - or T-induced elevations in total FSH (Fig. 3; Kamel and Krey, 1991).

The importance of progestin receptor occupation suggests that $\mathrm{P}$ works through a genomic mechanism to increase cell FSH stores. Such a hypothesis is also suggested by the $\geqq 6 \mathrm{~h}$ interval before FSH stores rise and the retention of this increase for up to $18 \mathrm{~h}$ following $P$ withdrawal. Although we have not tested whether FSH synthesis actually increases by quantifying FSH subunit mRNA levels in these cells, Attardi and Fitzgerald (1990) have recently demonstrated that $\mathrm{P}$ significantly elevates $\mathrm{FSH} \beta$ mRNA within $5-8 \mathrm{~h}$ in immature, estrogen-treated, female rats. Curiously, however, these changes were not accompanied by any alteration in cell FSH stores or secretion rate. Gharib and coworkers (1990) also reported that $6-12 \mathrm{~h}$ also transpires before T elevates FSH $\beta$ mRNA levels in rat pituitary cell cultures.

The findings that $\mathrm{P}_{\text {chronic }}$ selectively increases cell FSH levels contrast dramatically with the reports of Miller and his coworkers that $\mathrm{P}$ treatment only suppresses FSH synthesis by cultures of sheep pituitary cells (Batra and Miller, 1985; Phillips et al., 1988). Moreover, whereas P's actions on FSH depend on estrogen pretreatment in rat cells, such a pretreatment is not necessary in sheep cells. It is unlikely that differences in steroid administration can explain these differences since physiologic concentrations of $\mathrm{P}$ were used in both studics and Miller and his coworkers consistently noted P-induced suppression after shortterm (3-24 h) treatments. Significantly, acute exposures to $\mathrm{P}$ also failed to increase FSH secretion by the sheep cells. The most likely explanation for these variations in $\mathrm{P}$ action appears to be species differences in gonadotroph function, a concept previously stated by Miller and Wu (1981) to explain sheep-rat differences in estrogenic regulation of FSH synthesis and secretion.

The selective, P-induced increase in cell FSH levels observed in these cultures compromises investigation of secretagogue-stimulated LH/FSH secretion, especially if one quantifies release simply by measuring the amount of hormone secreted into the medium. This approach would result in discrepancies, such as $P_{\text {chronic }}$ suppressing LH release while increasing FSH secretion (Table 1; Drouin and Labrie, 1981), that are difficult to accommodate with current assumptions that GnRH stimulates the secretion of both hormones via a common intracellular mechanism(s). However, by standardizing gonadotropin secretion as the percentage of available cellular stores that are released, one obtains similar patterns for $\mathrm{P}$ modulation of $\mathrm{LH}$ and FSH release in response to $\mathrm{GnRH}, \mathrm{Ca}^{2+}$ iontophores or protein kinase $\mathrm{C}$ activators. As discussed previously (Krey and 
Kamel, 1990c), the similarities of responses to GnRH and $A 23187$ make it unlikely that $P$ regulates $\mathrm{GnRH}$ action only via the modulation of $\mathrm{GnRH}$ receptor number. In contrast, PMA-stimulated LH and FSH release is increased by $P_{\text {chronic }}$ treatment, a response that differs dramatically from that seen for $\mathrm{GnRH}$ and A23187; these differences raise questions about the role of protein kinase $\mathrm{C}$ activation in $\mathrm{GnRH}$ action. In any event, the observation that $\mathrm{P}$ induces parallel changes in the secretion of both gonadotropins, regardless of secretagogue, suggests that $\mathrm{P}$ utilizes the same or common mechanisms to control LH and FSH secretion.

Cellular LH and FSH stores consist of multiple immunoidentical isoforms that are separable by isoelectric focussing procedures and are characterized by differing bioactivities (Wakabayashi, 1977; Chappel et al., 1983; Hattori et al., 1983; Keel and Grotjan, 1985; Green et al., 1986). In rodents, the distribution and secretion of $\mathrm{I} H$ isohormones appears to be under steroidal control, a hypothesis based on the observations that, for secreted $\mathrm{LH}$, steroid treatments influences the $B: I$ ratio of bioactivity to immunoactivity (Mukhopadhyay et al., 1979; Solano et al., 1980; Sardanons et al., 1987). Although levels of bioactive FSH varied dramatically in the present studies depending on $P$ treatment, these changes generally paralleled those for immunoreactive FSH and shifts in $B: I$ were not observed.

In summary, our findings indicate that $\mathrm{P}$ exerts multiple, direct actions on FSH synthesis and secretion. The timing of each of these actions in vitro is consistent with the hypothesis that they play important roles in vivo to ensure patterns of circulating FSH sufficient for folliculogenesis and ovulation to occur during the rat estrous cycle. In cultured cells, periovulatory levels of $\mathrm{P}$ enhance GnRH-stimulated FSH secretion within $3 \mathrm{~h}$, an interval consistent with a physiologic role to maximize the size and duration of the preovulatory FSH surge on proestrous evening (Freeman, 1988). Within 6-9 h, the same progestin stimulus incrcases FSH synthesis in culturc and, as a result, elevates the number of FSH molecules available for release in response to GnRH. A similar interval separates the initial $P$ surge on proestrous evening and the secretion of the secondary FSH-only surge early on estrous morning (Freeman, 1988). This secondary surge influences the development of the next wave(s) of ovarian follicles (Greenwald and Terranova, 1988). The adenohypophysis is characterized by elevated FSH levels at the time of the secondary surge (Hasegawa et al., 1981) and, as assessed in vitro, displays the highest basal ratc of FSH rclcase and the highest ratio of FSH to LH secreted in response to pulsatile GnRH administration during proestrus or estrus (Fallest and Schwartz, 1990). Finally, after $\geqq 12$ h of exposure to $P$, the ability of GnRH to stimulate FSH secretion in cultured cells is suppressed; significantly, this time frame corresponds to estrus and diestrus, those days of the estrous cycle when serum FSH levels are at their nadir (Freeman, 1988).

\section{Acknowledgements}

The authors would like to thank Drs. G.D. Niswender and L.E. Reichert, Jr. for supplying the antiserum to oLH and the oLH tracer respectively. This research was supported by NIH grants HD 19236 (L.C.K.) and HD 18515 (I.Z.B.) and by RF 90075 from the Rockefeller Foundation.

\section{References}

Attardi, B. and Fitzgerald, T. (1990) Endocrinology 126, 2281-2287. Batra, S.K. and Miller, W.L. (1985) Endocrinology 117, 2443-2448.

Chappel, S.C., Ulloa- $\Lambda$ guirre, $\Lambda$. and Coutifaris, C. (1983) Endocr. Rev. 4, 179-211.

Denef, C., Hautekeete, E., Dewals, R. and DeWolf, A. (1980) Endocrinology 106, 724-729.

Drouin, J. and Labrie, F. (1976) Endocrinology 98, 1528-1534.

Drouin, I. and Iabrie, F. (1981) Endocrinology 108, 52-57.

DuBois, P.M., Morel, G., Forest, M.G. and DuBois, M.P. (1978) Horm. Metab. Res. 10, 250-252.

Fallest, P.C. and Schwartz, N.B. (1990) Biol. Reprod. 43, 977-985.

Freeman, M. (1988) in The Physiology of Reproduction, Vol. 2 (Knobil, E. and Neill, J.D., eds.), pp. 1893-1928, Raven Press, New York.

Gharib, S.D., Leung, P.C.K., Carroll, R.S. and Chin, W.W. (1990) Mol. Endocrinol. 4, 16201626.

Green, E.D., Boime, I. and Baenziger, J.U. (1986) Mol. Cell. Biochem. 72, 81-99.

Greenwald, G.S. and Terranova, P.F. (1988) in The Physiology of Reproduction, Vol. 1 (Knobil, E. and Neill, J.D., eds.), pp. 387-445, Raven Press, New York.

Handa, R.J., Roselli, C.E., Horton, L. and Resko, J.A. (1987) Endocrinology 121, 233-240.

Hasegawa, Y., Miyamoto, K., Yazaki, C. and Igarashi, M. (1981) Endocrinology 109, 130-135.

Hattori, M., Sakamoto, K. and Wakabayashi, K. (1983) Endocrinol. Jpn. 30, 289-296.

Hsueh, A., Erickson, E. and Yen, S.S.C. (1980) Endocrinology 104, 807-813.

Kamel, F. and Krey, L.C. (1982) Mol. Cell. Endocrinol. 28, 471-486.

Kamel, F. and Krey, L.C. (1991) Steroids 56, 22-29.

Keel, B.A. and Grotjan, Jr., H.E. (1985) Endocrinology 117, 354-360.

Kennedy, J. and Chappel, S. (1985) Endocrinology 116, 741-748.

Kiesel, L., Helm, K., Bertes, K., Maier, C., Rabe, T. and Runnebaum, B. (1987) J. Steroid Biochem. 27, 995-1002.

Krey, L.C. and Kamel, F. (1990a) Mol. Cell. Endocrinol. 68, 85-94.

Krey, L.C. and Kamel, F. (1990b) Mol. Cell. Endcorinol. 70, 21-29.

Krey, L.C. and Kamel, F. (1990c) Life Sci. 47, 1235-1241.

Krey, L.C., Kamel, F. and MacLusky, N.J. (1990) Mol. Cell. Endocrinol. 68, 95-103.

Lagace, L., Massicotte, J. and Labrie, F. (1980) Endocrinology 106, $684-689$

Liang, T., Heiss, C.E., Ostrove, S., Rasmussen, G.H. and Cheung, A. (1983) Endocrinology 112, 1460-1468.

Liang, T., Brady, E.J., Chcung, A.H. and Sapcrstcin, R. (1984) Endocrinology 115, 2311-2317. 
Martini, L. (1982) Endocr. Rev. 3, 1-25.

Miller, W.L. and Wu, J. (1981) Endocrinology 108, 673-679.

Mukhopadhyay, A., Leidenberger, F. and Lichtenberg, V. (1979) Endocrinology 104, 925-931.

Ortmann, O., Emons, G., Knuppen, R. and Catt, K.J. (1989) J. Steroid Biochem. 32, 291-298.

Padmanabhan, V., Chappel, S.C. and Beitins, I.Z. (1987) Endocrinology $121,1089-1098$.

Phillips, C.L., Lin, L.-W., Wu, J.C., Guzman, K., Milsted, A. and Miller, W.L. (1988) Mol. Endocrinol. 2, 641-649.

Sar, M. and Stumpf, W.F. (1978) I. Steroid Biochem. 9, 877.
Sar, M. and Stumpf, W.E. (1979) Cell Tissue Res. 203, 1-7.

Sardanons, M.L., Solano, A.R. and Podesta, E.J. (1987) J. Biol. Chem. 262, 11149-11155.

Solano, A.R., Garcia-Vega, A., Catt, K.J. and DuFau, M.L. (1980) Endocrinology 106, 1941-1948.

Thieulant, M.L. and Duvall, J. (1985) Endocrinology 116, 12991308.

Turgeon, J.L. and Waring, D.A. (1981) Endocrinology 108, 413-419.

Turgeon, J.L. and Waring, D.A. (1983) Am. J. Physiol. 244, E170E176.

Turgeon, J.L. and Waring, D.A. (1990) Endocrinology 127, 773-780. Wakabayashi, K. (1977) Endocrinol. Jpn. 24, 473-485. 